\title{
Tarihselciliğin ve Formalizmin Ötesinde Edebiyatın Tanıklığı
}

\section{Servet GüNDOĞDU*}

Witnessing of Literature Beyond Historicism and Formalism

Citation/@: Gündoğdu, Servet, (2019). Witnessing of Literature Beyond Historicism and Formalism, Milel ve Nihal, 16 (2), 375-391.

Abstract: In the historicist literary theory, which designs witnessing in the category of absolute trust and positions literature as a witness to the past, the literary work loses its literariness to become a historical document. Formalist literary theory emphasizes that literary works are linguistic beings rather than historical ones. In this way, it tries to preserve the literariness of the work as a witness to the linguistic sign of the work, not by looking at history. However, the limitation of the works with the network of linguistic relations renders them a closed object and makes them unhistorical. In the second half of the twentieth century, a new conception of literary history writing that advocates the role of the reader in the production of meaning rather than text or historical context is proposed. The liberal openness of the reader has achieved in the interpretation of the literary text and the semantic ambiguity of the word witness after the genocide disaster may seem to be related. At this point literary hermeneutics does not see literary works as witnesses of the past and linguistic sign. The literariness of the literary work comes from changing the meaning of the historical context in which it was produced. Literary works that have created a historical effect begin to produce their own history and time. Thus, literary works do not witness to the past or linguistic sign, but to the history which their produce and language itself.

Keywords: Historicism, Formalism, Witnessing, Literature, Suspicion.

* Dr. Öğr. Üyesi, Samsun Üniversitesi, İktisadi, İdari ve Sosyal Bilimler Fakültesi, Türk Dili ve Edebiyatı Bölümü [servet.gundogdu@samsun.edu.tr] ORCID: 00000001-8370-2726. 
Atıf/C: Gündoğdu, Servet, (2019). Tarihselciliğin ve Formalizmin Ötesinde Edebiyatın Tanıklığı, Milel ve Nihal, 16 (2), 375-391.

Öz: Tanıklığı 'mutlak güven' kategorisinde tasarlayan ve edebiyatı 'geçmişe tanık' olarak konumlandıran tarihselci edebiyat teorisinde edebi eser edebilik vasfını yitirip tarihsel vesikaya dönüşmektedir. Formalist edebiyat teorisi ise edebi eserlerin tarihsel varlık olmalarından ziyade dilsel varlık olmalarını ön plana çıkarırken eserin edebiliğini tarihe bakarak değil de eserin 'linguistik göstergeye tanıklığı' şeklinde korumaya çalışır. Buna karşın eserlerin dil-içi ilişkiler ağı ile sınırlandırılması onları birer "kapalı nesne" haline getirerek tarihsizleştirmektedir. Yirminci asrın ikinci yarısında metin veya tarihsel bağlamdan ziyade okurun anlam üretimindeki rolünü savunan yeni bir edebiyat tarihi yazımı anlayışı ileri sürülür. Okurun edebi metnin yorumlanmasında elde ettiği liberal açıklık ile ikinci dünya savaşından, bilhassa soykırım felaketinden sonra tanıklık kelimesinin de belirli bir semantik muğlaklığa bürünmesi birbiriyle ilintili görülebilir. Bu noktada edebi hermenötik edebi eserleri geçmişin ve linguistik göstergenin tanıkları olarak değil de 'dilin kendi kendisine tanıklığı' olarak ele alarak otonomi ve tarihsizleşme sorununu aşmayı dener. Edebi eserin edebiliği üretildiği tarihsel bağlamın anlamını değiştirmesinden ileri gelir. Böylesi bir tarihsel etki oluşturmuş edebi eserler bizatihi kendi zamanlarını üretmeye başlarlar. Böylece edebi eserler geçmişe veya dilsel göstergeye değil, kendi ürettiği tarihe ve dilin bizatihi kendisine tanıklık etmektedirler.

Anahtar Kelimeler: Tarihselcilik, Formalizm, Tanıklık, Edebiyat, Kuşku.

\section{Giriş}

Edebi eserlerin üretildikleri tarihsel ortamın, toplumsal yapının tanıkları olduğu yolunda ondokuzuncu asırda oluşan yaygın tarihselci bir yaklaşım vardır. Tarihselci edebiyat teorisi edebi eserlerin anlamının ancak kendi orijinal tarihsel bağlamı içerisinde tespit edilebileceğini, bu eserlerin tarihsel ortamı yeniden inşa etmede önemli bir kalkış noktası sağlayabileceğini, aynı zamanda "tarihi bilmemenin eserin yorumlanmasını tahrif edeceğini" 1 ileri sürer. Bir tarihsel ortamın edebi eserin yazımını ve yazarların hayatlarındaki farklı hadiselere ilişkin tecrübelerin onların yazma süreçlerini, düşünce, niyet ve psikolojilerini nasıl etkilediği, tarihsel ortama ait ilk okurlar için eserin ne ifade ettiği bu teorinin öncelikli sorularıdır. ${ }^{2}$

1 Rene Wellek, "Edebiyat Nazariyesi, Tenkidi ve Tarihi”, Ondokuz Mayıs Üniversitesi Eğitim Fakültesi Dergisi, çev.: Sıddık Yüksel, 2/1, (1992): 316.

2 Her bir eser ancak kendi döneminde kendi şartlarında anlaşılır, başka döneme göre anlaşılmamalıdır düşüncesi en ileri boyutta Dilthey'da tecessüm etmiş görünmektedir. Dilthey, Hermeneutik ve Tin Bilimleri kitabında "Homeros'un şii- 
Edebi eserlerin tanıklığı sorusu, bu öncelikler üzerinden kurgulanıp eserin özü doğrudan tarihsel hadiselere veya bağlama tanıklık noktasında açıkladığında, bu soru tarihsel olduğu kadar yapısal bir tartışmayı da beraberinde getirmektedir. Çünkü tarihsel bağlama tanıklık konusu burada zorunlu olarak metin-içi ve metin-dışı bağlam diye bir ayrımı peşinen varsaymaktadır. Bu varsayımda metiniçi (metnin muhtevası, gösteren), metin-dışı bağlama (tarihsel, sosyolojik, kültürel gösterilenlere) referansta bulunabilmekte veya indirgenebilmektedir. Metin-içi ve metin-dışı şeklinde ayrım yapıld1ğında ise metnin içinin metnin dışına veya metnin dışının metnin kendisine tanıklığı şeklinde bir tasarım ortaya çıkmaktadır. Burada birbirini takip eden, doğrulayan ve birbirinin yerine geçebilen, neticede referansiyel bütünlük (referential totality) oluşturan bir çifte tanıklık durumu oluşmaktadır. Metin tarihsel bağlama tanıklık ederken öte taraftan tarihsel bağlam da metne tanıklık etmiş olur.

Bu noktada beliren sorun Grek düşüncesinden itibaren oluşmaya başlamış söylemsel farklılaşmanın bir diğerinin otonomisini ihlal eder tarzda ortadan kaldırılmasına ilişkindir. Edebi eser metnin gerisinde varsayılan bir dünyaya, tarihe tanıklık ettiğinde veya Hegel ve onu izleyen Dilthey'ın ifadesiyle tinin şeyleşmesi (objectification of spirit) hadisesi olarak düşünüldüğünde mecburen türü (genre) ve kimliği (identity) değişmekte, artık edebi olma vasfını yitirmektedir. 'Edebi eserin tanıklığı' ifadesinin kendisi bu nedenle kendi içerisinde bir çelişki üretmektedir. Çünkü doğrulayıcı bir tanıklık icra ettiği anda edebi eser olmaktan çıkıp tarihsel vesikaya (historical evidence, historical witness), kayıt veya kaynağa dönüşeceği için türü ve kimliği de değişmiş olur. Dolayısıyla bu açıdan bakıldığında artık ona edebi eser demek mümkün değildir.

$\mathrm{Bu}$ açıdan edebi eserin tanıklığından önce vesikaya indirgenip indirgenemeyeceği sorunu daha ontolojik bir sorun olarak dikkat çeker. Edebi eserin tanıklık karakterinden ziyade bir vesika olarak görülmesi, sanat eseri (work of art) olarak değil de diğer yazılı belgelerin yanında bir belge olarak görülmesi çok daha kritiktir. Çünkü bu

rinde şairin tekilleşmesi doğrultusu içinde hareket ettiği sınırlar bizzat zamanının ve çağının sınırlarıdır. Onun tüm ufku aristokratik toplum tarafından kuşatılmıştı" derken de "Shakespeare'in eserleri aslında kendi döneminin tinini yansıtırlar. Doğa bilimlerinin ve mekanizmin doğuş ve yükseliş dönemidir bu dönem" dediğinde de benzer bir tarihselcilik sorununu üretir. Wilhelm Dilthey, Hermeneutik ve Tinbilimleri, çev.: Doğan Özlem (İstanbul: Paradigma Yayınları, 1999), 49, 56 
durumda edebi eser arşiv belgeleri, resmî belgeler, mahkeme kayıtları, vakanüvislerin yazdıkları türünden bir vesikaya dönüşmektedir. Vesika denildiğinde artık bir tarihsel gerçekliği pekiştirme, tanıklık etme ve delillik işlevi edebi eserin tekil bir amacına dönüşmektedir.

Tanıklık edebi eserin iş görmesi, bir işlevi anlamına gelir. Vesika veya belge denildiği anda ise edebi eserin edebiliği kaçınılmaz olarak ortadan kalktığ 1 ve türü de değiştiği için, sadece ne tür bir iş görüp görmeyeceği değil, ontolojik yapısında açık bir değişim söz konusu olur. Dolayısıyla sanat eseri olmaktan çıkıp, eserin durduğu düzlem değişerek bir epistemolojik düzleme aktarılmış olmaktadır. Çok anlamlılıktan çıkıp tek anlamlılığa doğru, dış dünyaya referansı olan, dolayısıyla doğrulanıp-yanlışlanabilen farklı bir düzleme geçiş söz konusu olmaya başlar. Tarihi vesika olarak kabul edildiğinde veya kendi dönemine tanıklık ettiği ileri sürüldüğü andan itibaren edebi eserin türü ve kimliğine ilişkin kritik bir sorun ortaya çıkmaktadır.

Yirminci asrın hemen ilk çeyreğinde metin-içi bağlam ve metindışı bağlam anlayışının ürettiği tür sorunuyla beraber referans sorununu gidermek adına Roman Jakobson'un metnin-dışı tasavvurunun eserin edebiliğini ihmal etmesi üzerine yoğunlaşması dikkat çeker. Belli bir eseri tarihsel vesika veya belge değil de edebi kılan hususun ne olduğu onun formalist edebiyat teorisinin asli konusudur. Jakobson edebi eserlerin tarihsel varlık olmalarından ziyade dilsel varlık olmalarını ön plana çıkarırken eserin edebiliğini (literariness, literaturnost) metin-dışı bağlam olarak görülen tarihe bakarak değil de eserin içsel yapısına, formuna veya 'dilsel göstergeye tanıklık' şeklinde anlayarak belirmeye çalışır. ${ }^{3}$ Çünkü artık burada sadece edebi esere ilişkin değil, daha ziyade dile ilişkin önemli bir perspektif değişimi söz konusudur. Dilin gerisinde dili yönlendiren sabit bir gerçeklik olmadığı, dilin kendi içinde otonom olduğu düşünüldüğünde tanıklık da bu defa Saussure'ün Dil ve Söz ayrımindan hareketle ancak dil-içi bir hadiseye dönüşmektedir. Fakat bu sefer de eserlerin metin-içi veya dil-içi ilişkiler ağı ile sınırlandırılması onları birer "kapalı nesne" haline getirerek tarihsizleştirmektedir.

3 Roman Jakobson, "Linguistics and Poetics", Language in Literature, ed.: Krystyna Pomorska and Stephen Rudy (Cambridge MA: Harvard University Press, 1987), 62-94. 
Edebi eserin tarihsizleştirilmesi ile büsbütün tarihsel vesikaya indirgenmesinin ötesinde edebiyatın hala tarihle otonomi sorunu üretmeksizin bir ilişkisinin kurulabilmesi mümkün ve zorunlu görünmektedir. Zorunludur, çünkü edebi eserler sonuçta yine edebiyat tarihinin bir parçası olmaları nedeniyle kaçınılmaz olarak bir tarihe tanıklık ederler. Ancak bir sanat eseri kendine özgü bir kimliği, orijinalitesi veya biricikliği olduğu için veya Gadamer' in işaret ettiği sürpriz ${ }^{4}$ vasfına sahip olduğu için, daha açık ifadeyle edebi eser farklı bir şey söylediği için bu durumda mecburen edebiyat tarihinde bile olsa bir tür kırılmaya, yön değiştirmeye yol açar. Sadece bilinen şeylerin aşina olunan bir söyleme tarzında söylendiği bir durumda bir metni edebi eser olarak alımlamak veya tecrübe edebilmek mümkün değildir. Edebi eserin edebi eserliği edebiyat tarihinde bir kırılmaya veya yön değiştirmeye yol açmasından, diğer deyişle ait olduğu tarihsel bağlamın anlamını değiştirmesinden ileri gelir.

Ama bu durumda da böylesi bir tarihsel etki oluşturmuş edebi eserler bizatihi kendi zamanlarını üretmeye başlarlar. Farklı bir deyişle, edebi eser kendi ürettiği zamana veya tarihe tanıklık etmektedir. Edebi eserin tarihe tanıklık edip edemeyeceği veya edebi eseri tarihsizleştirerek salt kendi metinselliği üzerinden ele alınıp alınamayacağı soruları aşırı muğlak ve tek taraflı ele alınmaması gereken sorulardır. Tarih denildiğinde hemen metin-dışı tarih, diğer deyişle içinde üretildiği tarihsel olaylar anlamında tarih veya tarihsel dönem kelimesi kullanılmaktadır. Edebi eser denildiğindeyse metnin içsel yapısı anlaşılmaktadır. Oysa edebi eser zorunlu olarak edebiyat tarihinde ürettiği tarihsel kırılma esnasında veya sürpriz bir dünya (ortam) oluşturması anlamında, böylesi birçok-anlamlılık vasfına sahip olması dolayısıyla mecburen kendi zamanını, kendi tarihini üretmeye başlar. Homeros'un Odysseia adlı eseri bir tarihsel ortam içinde söylenmiştir, ama bununla beraber aynı zamanda bizzat kendi ürettiği tarih, kendine ait bir tarih oluşmaya başlar.

Edebi eser elbette belli bir tarihsel dönem içerisinde, belli bir eserin üretilmesini, yani o eserin üretilmesini mümkün kılacak şartların veya birikimin oluştuğuna tanıklık etmektedir. Bir eser yazıl-

4 Hans-Georg Gadamer, "Aesthetics and Hermeneutics", Philosophical Hermeneutics, trans. and ed.: David E. Linge (Berkeley, Los Angeles, London: University of California Press, 2008), 101. 
dığı zaman o dönemdeki kelime, tür ve üsluplar, literatür, perspektif çeşitliliği, şartlar o eserin oluşmasını mümkün kılacak kadar kümülatif ve sofistike bir hale gelmiş demektir. Söz gelimi Cervantes'in Don Kişot'unu Homeros'un yazması mümkün değildir. Veya Orhan Pamuk'un Kara Kitap'ını Şeyh Galib'in yazması da. Çünkü henüz öyle bir birikim yoktur. Bu bağlamda herhangi bir edebi eser kendi tarihine ancak böyle bir birikimin, alt yapının oluştuğu ölçüde tanıklık edebilir. Dikkat edilirse edebi eser belirli bir tarihsel hadiseye tanıklıktan ziyade, daima bambaşka boyutlarda tarih kavramıyla ilişki içerisine girmektedir.

Edebi eserin kurgu olması bağlamında tarihe tanıklığı veya tarihle ilişkisi nedir? Edebi eserin kurgu olması, eserin içinde bulunduğu tarihsel bağlamdaki fiili durumdan başka bir anlam dünyas1nın inşası demektir. Paul Ricoeur "Bütün sanat eserleri dünyayı temsil eder, diğer deyişle, esasen bir varlık artışı ve bu bakımdan varlığı çoğaltan bir dünyayı gösteren bütün sanat eserleri bir tür kehanet, promesse de bonheur"dür: $\mathrm{O}$ bana kendimi proje edebileceğim bir dünya açar" ${ }^{5}$ dediğinde benzer bir noktaya işaret etmektedir. Bu bağlamda da o, metne tanıklığın ancak metnin daima bir bağlamlaştırma (contextualization) ile yeni bir bağlama yerleştirilmesi (re-contextualization) ile mümkün olabileceğini savunur. Ona göre okuma denilen şey bu ikisinden oluşmaktadır. ${ }^{6}$ Bunun anlamı edebi eser bir kurgu olarak daima tarihsel bir durumun ötesine gittiği için, o tarihsel durumun yeni bir gözle görülmesini sağlar.

Daha açık ifadeyle edebi eser aslında bir kritik (eleştiri) olarak var olur. Dolayısıyla edebi eser ancak kendi tarihinin yeni bir gözle görülmesini sağlayacak bir kritiği olarak kendi tarihine tanıklık eder. "'Eleştiri', bütünüyle değilse de özü bakımından tanıklı̆̆ın eleştirisidir, yani tanıklığın sınanmasıdır." 7 Aynı zamanda daha sonraki tarihsel dönemleri de etkileyerek ilk bağlamları hakkında da farklı tasarımların ortaya çıkmasına tanıklık edebilir. Özellikle Platon'un Devlet adı kitabının bir ütopya olarak başta kendi tarihi dönemine, tersinden bir eleştiri olarak tanıklık etmesi gibi.

5 Paul Ricoeur, Hafiza, Tarih, Unutuş, çev.: M. Emin Özcan (İstanbul: Metis Yayınlar1, 2012), $316 \mathrm{vd}$.

6 Paul Ricoeur, Hafiza, Tarih, Unutuş, 163.

7 Paul Ricoeur, Zaman ve Anlatı: İki - Tarih ve Anlatı, çev.: Mehmet Rifat (İstanbul: 
Tarihselciliğgin ve Formalizmin Ötesinde Edebiyatın Tanıklığı

Bu bağlamda edebi eserin tarihle ilişkisi kaçınılmaz olduğu gibi tarihsel dönemlerle de böyledir. Bir eserin farklı dönemlerde nasıl algılandığı, yorumlandığı konusu ister istemez bir tarihle bağını ortaya koymaktadır. Yirminci asrın ikinci yarısında bu düşünceden hareketle metinlerin anlamını okurların metinlerden anladıkları şeyden ibaret olarak varsayan, metin veya tarihsel bağlamdan ziyade okurun anlam üretimindeki rolünü savunan yeni bir edebiyat tarihi yazımı anlayışı ileri sürülür. ${ }^{8}$ Okurun yükselişinden sonra artık burada edebiyatın tarihe tanıklığı ne anlama gelir? Bu soru etrafında edebi eserin tanıklığının bir kritik bir başka yönü üzerinde daha durmak gereklidir.

\section{Tanıklığın Semantik Dönüşümü}

Yirminci asrın ikinci yarısında giderek belirginleşen bir tanıklı edebiyatı (witness literature) ${ }^{9}$ kavramı dikkat çekmektedir. Okurun edebi metnin yorumlanmasında elde ettiği liberal açıklık ile ikinci dünya savaşından, bilhassa soykırım felaketinden sonra tanıklık kelimesinin de belirli bir semantik dönüşüme uğraması birbiriyle ilintili görülebilir. Tanıklık burada artık başka bir şeyin yerine geçen ve yerini alan göstergelerin kullanımı şeklinde bir yeniden-inşa olmaktan farklı bir anlama gelmeye başlar. Tanıklık modern edebiyatta çoğu zaman hukuki-tarihsel bir terim olarak kullanımının ötesinde dilin çağın acılarına tanıklığını kayıt altına alma veya bir tür protesto biçimi olarak görülür. ${ }^{10}$ Yazarak direnme veya yazarak unutma gibi bir pratik içerisinde zulüm görmüş mağdurun tanıklı̆̆g aslında yazar figürünün merkezde tutulduğu, okurun ve metnin

8 Hans Robert Jauss, "Bilimsel Bir Yazın Tarihinin Çağırışı", çev.: Tevfik Turan, Bağlam Dergisi 2 (İstanbul: 1980): 89-122.

9 Tanıklık yirminci asırda yeni bir edebi tür olarak da görülür. E. Wiesel, “Yunanlılar trajediyi, Romalılar mektubu, Rönesans soneyi icat ettiyse, bizim neslimiz de yeni bir edebiyat icat etti: tanıklı" der. Elie Wiesel, "The Holocaust as a Literary Inspiration", Dimensions of the Holocaust, ed.: Elliot Leifkovitz (Evanston, Illinois: Northwestern University Press, 1977), 10. 'Tanıklık edebiyatı' kavramına üzerine kavramsal bir sınır belirleme çabası içerisinde olan bir çalışma için bk. Laura Sasu, "Witness Literature-A Conceptual Framework", Bulletin of the Transilvania University of Braşov, Series IV: Philology \& Cultural Studies, 6/2, 712.

10 İlhan Berk, "Güzel Devedikeni" isimli şiirinde "Dili, acının tarihi. Bir tanıklık, çağına." derken Turgut Uyar'dan söz eder. 
unutulduğu tarihselci yaklaşımın bir tür yeniden sunumudur. ${ }^{11}$ Dolayısıyla edebi eser daima tarihsel bir felakete geriye dönüşlerle ilerlerken okur da edebiyatın tarihe olan tanıklığına pasivize edilmiş vaziyette tanık olur.

Dikkat edilirse tanıklığın tarih veya edebiyat tarafından ele alındığında anlamı açıkça değişebilmektedir. Daha yakından bakılarak tanıklı̆̆ın salt doğrulamak üzere var olma durumunun ötesinde hala ne tür bir anlam alanı oluşabileceği üzerinde durmak yararlı olabilir. Öncelikle tanıklık bilhassa yaygın hukuki kullanımı bağlamında nasıl bir şeydir? Tanıklıkta ilkesel olarak kişi güvenilir olarak konumlandırılmalıdır. Bir kişi kendisini bir hadisenin tanığı olarak kabul ettiği durumda artık onun söyleyeceği sözlerin bir doğruluk iddiasına sahip olduğu bilinir. Tanık bize yaşanmış bir gerçekliği dilde yeniden temsil veya ifade (beyan) şeklinde sunar. Tanık daima oradadır, olayı görmüştür ve olayı aktarmaya hazırdır. Fakat 'tanıklık' aynı zamanda hem gündelik hayatın görece dışına çıkmış ve bir daha tekrarlanamayacak bir hadiseye orada olması hasebiyle kişiyi ait kılar hem de o hadisenin belirli bir mesafede d1şında, tarafsız bir noktasında olduğunu varsayar. Tanığın belirli bir hadiseye aidiyet ve mesafesi onun ayn zamanda hem ilkesel olarak güvenilir hem de kuşkulu ifadelerini kulak verilmesi gereken bir söz düzeyine taşır.

Tanığın ifadesinin kuşkulu boyutu ile edebiyatın ürettiği kuşku arasında bir benzerlik kurmak güç olmayacaktır. Romantizmden bu yana birçok edebiyatçı yaşadıkları öznel tecrübeler ile bu tecrübeleri tanımlamak için kullandıkları kelimeler arasında bir mütekabiliyet ilişkisi olamadığını dile getirir. ${ }^{12}$ Gerçeği bütünüyle ve güvenilir düzlemde dile getirebilen bir temsil olarak tanıklığın imkânsız olduğu düşünülürse edebiyatın tarihe tanıklığı tarihselci perspektiften hala meşru kabul edilebilir mi? Edebi eserlerin tarihin tanıkları olduğ yolundaki tarihselci yaklaşım aslında ne tür bir 'tanıklık' tasarımına sahiptir? Büyük ölçüde bu tanıklık 'mutlak güven' varsayımına sahip görünür ve burada tanık ifadelerinin kuşku boyutu

11 Türk edebiyatında da darbeler sonrası ortaya çıkan acıları anlatan anlatılar tanıklık edebiyatı için örnek olarak görülür. Çimen Günay Erkol, “Tas, Üstüne Taş Koymak: 12 Mart Romanlarında Görgü Tanığı Belleğinin Yazınsallaştırılması", Nasıl Hatırlıyoruz? Türkiye'de Bellek Çalışmalar (İstanbul: Türkiye İş Bankası Yayınlar1, 2011), 41-63.

12 Bu durum için Türkçede en bilindik örnek Orhan Veli'nin "Anlatamıyorum" isimli şiiridir. 
göz ardı edilmektedir. Aynı zamanda bu durum 'tanığa tanıklık' olgusunun da unutulmasına neden olur. Edebi eserlerin tanıklıklarındaki bu kuşku (kurgu), diğer deyişle temsile direnen yönünün baskılanması onların kolayca tarihyazımı için tarihsel vesika olarak konumlandırılmasına neden olur.

Tanıklığa kuşku hangi koşullarda oluşur? Bu soru Ricoeur'ye göre "tanıklığın anlamının özüne yaklaşma şansını" bize verebilir. Ricoeur cümlenin hemen devamında şöyle diyecektir: "Gerçekten de yaşanmış bir sahnenin algılanmasıyla başlayıp, anının akılda tutulmasıyla süren, sonra da olayın parçaların yerine konulmasını açıklayıp anlatma aşamasına odaklanan işlemler zincirinin her halkasında kuşku kendini gösterebilir." ${ }^{13}$ Ricoeur tanıklığın kurgusallığına (anlatısallık) vurgu yapıp kuşku yönünü öne çıkardığında onun gözden düşürülmesine çalışmaz. Tersine tanıklığın kuşku üreten vasfının ona itibarını veren şey olduğunu ima eder. Çünkü tanık tek başına kendi kendisini tanık olarak ilan edemez. Tanık hem hadisenin gerçekleştiği anda tam olarak orada olduğunu söyler hem de kendisine inanılmasını bekler. Kendisine inanılmasını istediği, gerçekliğe sadık olduğunu deklare ettiği bu durumda da meydan okuyucu bir çağrı olarak 'inanmıyorsanız bir başkasına sorun' diyecektir. Dolayısıyla hadise kamusal bir alanda olmuştur ve tanık da kamusal alanın diliyle konuşmaktadır. Tanıklık bu süreçte daima tam anlamıla şahit olunamayan veya dile getirilemeyen bir hadiseye yönelik olarak ortaya çıkan bir kuşku etrafında şekillenir. ${ }^{14}$

Ricoeur sadece bir hukuki süreci ele alırken değil, güzele ilişkin tecrübeyi (estetik tecrübe) ahlak alanına aktarırken de tanıklık kavramına önem atfeder. Bundan da önemlisi tanıklık sorusu benzemezlik ve iletilebilirlik sorununa yönelir. Dolayısıyla özgün olanın diyaloji oluşturup oluşturamayacağı sorunu Ricoeur için önemlidir. “Ama, estetik deneyimin yan alanlara aktarılabilme niteliği üzerine de düşünmek istiyorsak, o zaman yapıtın başlıca iki özelliğini de hesaba katmamız gerekir: Benzersizliğini ve iletilebilirliğini (bu

13 Ricoeur, Hafiza, Tarih, Unutuş, 184.

14 Dil ve kuşku konusunun edebi metin bağlamında detaylı bir analizi için bkz:: Atiye Gülfer Gündoğdu, “Okurla Dil Arasındaki Şüphe ve Güven İlişkisinin Edebi Metnin Anlamına Etkisi", Dinbilimleri Akademik Araştırma Dergisi 17/2, (2017): 93-110. Aynı zamanda kuşku ve güven konusunu hadis tartışmalarının ürettiği tarihsel bilinç bağlamında ele alan başka bir özgün çalışma için bkz.: Burhanettin Tatar, "Tarihsel Hadis Bilincinin Rehabilitasyonu", Ondokuz Mayls Üniversitesi Ilahiyat Fakültesi Dergisi, 2001, 12-13, 583-593. 
ikinci özelliğin içerdiği kendine özgü evrensellikle birlikte). Etik alanında kalmak için, benzersizliği ve iletilebilirliği birleştiren sanat yapıtı tanıklık kavramını düşünmede de bir model oluşturamaz mi?"15

Akira Kurosawa'nın 1950 tarihli Rashomon isimli filmi, belirli bir hadiseye ilişkin geriye kırılmalarla ilerleyen tanıklığın başka kimseler tarafından her dile getirilişinde olaya ilişkin düşüncelerimizin değiştiğine tanık olmamıza yol açar. Bu filmdeki anlatı boyunca, ormanda ölü bir şekilde bulunan samurayın başına ne geldiği sorusuna ilişkin bir başkasının tanıklığına müracaatın her durumda bir diğer tanığı doğrulamayabileceği izlenir. Bir tanığın söylediği diğerini doğrulamadığına göre birileri doğruyu söylemiyor demektir. Bu film gerçekliğin kararsız tabiatına, perspektifin sübjektivitesinin süregelen bir anlatı boyunca doğrulanmasının güçlüğüne vurgu yaptıkça tanıklığı imkansızlaştırır veya güvenilmezleştirir.

Tanıklığın gerçekliğin kararsız tabiatı bağlamında gözden düşürülmesi olayın bir yönüdür. Diğer yön ise Adorno' da görünür. $O$, "Auscwhitz'ten sonra şiir yazılamaz"16 dediğinde tarihin daha önce tanık olmadığ 1 böylesi bir felaketi dile getirme noktasında edebiyatın tarih boyunca ürettiği dilsel imkanların dahi hazırlıksız yakalandığını ima eder. Burada Adorno Auscwhitz'i tarihsel bir dönüm noktası olarak belirlemek isterken tanıklığı imkânsız hale getirir ve bu durumda gerçeklik dili aşar. Bu yaklaşım tecrübeyi dil aracıl1ğıyla ifadeye dönüştürmenin gerçekliğin (masumiyetin) tahrifi anlamına geldiği romantik yaklaşıma benzer. Yine de hala şiir ve gerçeklik arasında kategorik olarak bir farklılık burada muhafaza edilir.

Buna karşılık Derrida tanıklığı ve şiiri "radikal tekillik" olarak ortak bir tanıma kavuşturur. O, tanıklıktan poetik ve politik bir konu olarak söz eder ve özellikle poetika bağlamında düşündüğ̈̈nde tekillik (singularity) konusunu ele alır. ${ }^{17}$ Fakat bu tekillik salt

15 Paul Ricoeur, Eleştiri ve Inanç: F. Azouvi ve M. De Launay ile Söyleşi, çev.: Mehmet Rifat (İstanbul: Yap1 Kredi Yayınları), 2010, 247.

16 Theodor Adorno, "Kültür Eleştirisi ve Toplum”, Edebiyat Yazıları, çev.: Sabir Yücesoy ve Orhan Koçak (İstanbul: Metis Yayınları, 2008), 179.

17 Jacques Derrida, "Poetics and Politics of Witnessing", Sovereignties in Question: The Poetics of Paul Celan, ed.: Thomas Dutoit and Outi Pasanen (New York : Fordham University Press, 2005), 65-96. 
şiirin tekilliğidir. Bu tekilliğin okurla ne tür veya ne ölçüde bir diyalog oluşturacağı sorusuna bir cevap aranmaz. Benzer şekilde Blanchot, "hala yaşamın ve ölülerin ötesinde konuşulması gereken bir söz, "doğrulamanın yokluğuna tanıklık ediyor"18 der. Burada söylenmesi gereken söz henüz söylenmemiştir. Söylenmediği için de bir tanıklığa da izin vermez. Sadece böyle bir ihtimal bir tanıklık ihtimalini ima eder. Böylece burada okura imkânsız bir tanıklık vaat edilir. Okuma henüz eseri okumadan önceki varlığına bir tür tanıklıktır. Derrida "“evet, bu eser benden önce, bensiz vardı, tanıklık ediyorum" der" ${ }^{19}$ Derrida'nın burada ürettiği farklılık eserin tanıklığından ziyade okumanın bir tür tanıklık olduğuna yönelik değiştirdiği vurguda belirginleşir.

\section{Hadiseleşme ve Sıradanlık}

Hannah Arendt felakete tanıklıktan söz ederken mağdurun tanık olamadığına dikkat çeker. Çünkü ona göre kötülük sıradanlaştığında artık anlatılabilir olmaktan da çıkar. Öncelikle bir hadise gündelikliğinden veya olağanlığından ayrıştığı ölçüde ona bir ölçüde yakın olanı kendisine tanık kılar. Arendt'in sözünü ettiği “korkunç, fikre ve zikre direnen kötülüğ̈̈̈n sıradanlığ1" ${ }^{20}$ artık tanıklık kavramını ortadan kaldırır. Geride hiçbir tanığın kalmasının istenmediği durumlarda hala kötülüğün bir ölçüde de olsa kötülük olarak kabul edildiği anlaşılır. Oysa herkesin tanık olduğu, ama tanığın neye tanık olduğunu fark edemediği bir durumda kötülük artık sıradanlaşmiştır. ${ }^{21}$

Buraya kadar söylenilenlerden sonra edebiyatın tanıklığının dilin çağın acılarına tanıklığını kayıt altına alması durumundan daha önemli bir boyuta sahip olduğu ileri sürülebilir. Edebiyat dilin tan1ğıdır. O, dilin tanığı olduğu için sadece kendi zamanından söz etmez, Hesiodos'un işaret ettiği gibi “olanı, olacağı, olmuşu” 22 aynı

18 Maurice Blanchot'dan alıntılayan Jacques Derrida, "Poetics and Politics of Witnessing", 96.

19 Jacques Derrida, Edebiyat Edimleri, çev.: Mukadder Erkan ve Ali Utku, (İstanbul: Otonom Yayıncılık, 2009), 73.

20 Hannah Arendt, Kötülüğün Sıradanlı̆̆ı: Adolf Eichmann Kudüs'te, çev.: Özge Çelik, (İstanbul: Metis Yayınları, 2012), 258.

21 Rashomon' da üç farklı tanıktan hadise dinlenilip olay karmaşıklaştığında mağdurun ruhunun da olaya tanık olarak çağrılması aslında mağdurun tanık olarak gerçekte dinlenilmesinin imkansızlığını doğrular.

22 Hesiodos, Theogonia - İşler ve Günler, çev.: Azra Erhat ve Sabahattin Eyüboğlu, (Ankara: Türk Tarih Kurumu Basımevi, 1977), 106. 
anda söyler. Fakat Paul Celan'ın epigrafta verilen mısraları üzerinden şu soruyu sormak kaçınılmazdır, bütün zamanların tanığı olan şiire kim tanıklık eder? Edebiyatın tanıklık ettiği şey belirli bir tarihsel hadise olmaktan ziyade, o hadisenin dilde ne ölçüde kendisini görünür kılabileceği hususudur. Dolayısıyla bir tanıklık asla belirli bir tarihsel hadiseye değil, daha ziyade tanığın dille kurduğu ilişki bağlamında dile tanıklığıdır. Zaten tarihsel hadiseler dille kurulan ilişki düzeyinde bir kavranabilirliğe sahiptir. Kısacası tanıklığın kendisi değil, dilden bağımsız bir tanıklık imkânsızdır. Gadamer poetik sözden bu nedenle 'dilin kendi kendisine tanıklığı' olarak söz eder.

Edebiyat dilsel sanat olması hasebiyle onun gündelik konuşma ve tarihyazımının dille kurduğu ilişkiden farklılığının belirlenmesi daima en kritik sorundur. Dil zamansal bir akış halindeyken gündelik konuşmanın nerede bitip edebiyatın nerede başladığı, edebiyatın nerede bitip tarihyazımının nerede başladığı soruları bir biçimde güçlük üretmeyi sürdürmektedir. Bu noktada tanıklık kelimesi bu güçlüğü aşmakta önemli bir rol üstlenebilir. Gadamer hermenötiğinde tanıklık kelimesi hukuki bağlamı göz ardı edilmeden iki farklı yerde kullanır. Bunlardan birisi tarih diğeri de şiirdir. Gadamer'e göre "poetik söz, kendi kendisine tanıklık eden ve kendisini doğrulayabilecek hiçbir şeyi kabul etmeyen bir ifadedir." 23 Sadece orada oluşu (being there) poetik sözün bizim kendi varlığımıza tanıklık etmesi için yeterlidir. ${ }^{24}$

Tanıklığın daima sıradan bir durumun ötesine geçmiş, belirli bir yorumsal diyalogun döndüğü bir hadiseye, bir hadiseleşme (Ereignis) olgusuna tanıklık olduğu belirlendiğinde, sıradan ve sıra-dışı ayrımının nerede ve nasıl fark edildiği sorulmalıdır. Bir gündelik durum içerisinde belirli bir an nasıl olup da 'hadise' halini alır? Bir durumun, hadise halini alması demek artık onun belirli bir durağanlığından çıkıp tam artık bittiği veya geçip gittiği düşünüldüğünde aktif bir katılım konusu halini alması anlamına gelir. Çünkü hadise artık bir özdeşlikten ziyade farklılığın içinde hareket ettiği dil durumunu açığa çıkaran şeydir. Burada ortaya çıkan

23 Hans-Georg Gadamer, "On the Contribution of Poetry to the Search for Truth", The Relevance of the Beautiful and Other Essays, ed.: Robert Bernasconi, trans.: Nicholas Walker, (Cambridge: Cambridge University Press, 1986), 110.

24 Gadamer, "On the Contribution of Poetry to the Search for Truth", 115. 
dil durumu Levinas'ın söyleme (said) ve söylenen (saying) ayrımı üzerinden daha doğru anlaşılabilir.

Tanıklık, olmuş bir hadisenin, söylenenin izah edilmesinde ortaya çıkan güçlükler kadar, henüz olmamış olanın, söylenmemiş olanın büyüselliği nedeniyle de önemlidir. Levinas'ın “ölüme sadece başkasının ölümünde tanıklık ederiz" düşüncesinden de anlaşılabileceği üzere tanıklık kişinin kendi geleceğine ilişkin bir projeksiyon üretme durumunda başkalarının hikâyelerine karşı sorumluluk hissetme durumudur. Hiç kimse kendi başına da gelme olasılığı olduğu için başkalarının ölümüne, acılarına büsbütün kayıtsız kalamaz. Tanıklık pasif bir durum veya bir tercih olmaktan öte kişinin kendisini kaptırdığı, bir tür iman ve itaat ettiği hadiselerde daha belirgin şekilde açı̆̆a çıkar. ${ }^{25}$ Ancak “'Efendim!' diyen özne Sonsuz'a tanıklık eder." 26 Daha açık ifadeyle sonsuzluk, ölüm ve tanrı gibi bütüncül bir tecrübe hadise konusu haline getirilemeyecek durumlarda kişi kendisini bir şeylere 'tanıklık' ederken bulur. Ama tanıklıkla gelen ifşayla beraber, bu ifşaya tanık olan kimse artık bir başkasıdır. Bu nedenle Levinas'a göre "tek saf tanıklık Sonsuz'a tanıklıktır." 27

\section{Tarihi Kuran Sanat}

Heidegger'in son yazılarında, özellikle Sanat Eserinin Kökeni'nde dile getirdiği husus sanatın tarihsel oluşu ve edebi üretimin bütün tarihsel dünyaları kuran bir faaliyet oluşudur. Burada cevaplamaya çalıştığı soru sanat eserinin şey'den nasıl ayırt edileceğidir. Fenomenolojinin "şeylerin kendilerine dönmek" sloganını sanat eseri ve varlık düşüncesi bağlamında ele alan Heidegger'in "şeylik" (thingness) felsefesine bakıldığında tanıklık farklı bir anlamda açığa çıkmaktadır. Bir çiftçinin ayakkabılarını gösteren Van Gogh tablosuna bakıldığında vurguladığı konu öncelikle eserlerin de şeyler gibi var olmalarıdır. Sanat eserinin kendisi bizatihi bir şey olmasının yanında aynı zamanda şeysel bir boyuta da sahiptir. Mimaride taş ve

25 Hiristiyanlıkta da şehit (martyre) kelimesi İslamiyet'le benzer şekilde şahitlik kökünden gelerek, kendi inancına (imanına) veya hakikate tanıklık eden kimse anlamina gelir. https://www.etymonline.com/word/martyr\#etymonline_v_9661, Erişim Tarihi: 23.10.2019; Isaiah Berlin, Romantikliğin Kökleri, haz.: Henry Hardy, çev.: Mete Tunçay (İstanbul: Yapı Kredi Yayınları, 2004), 28.

26 Emmanuel Levinas, "Etik ve Sonsuz", Sonsuza Tanıklık, haz.: Zeynep Direk ve Erdem Gökyaran, çev.: Özkan Gözel (İstanbul: Metis Yayınları, 2003), 335.

27 Emmanuel Levinas, "Tanrı ve Felsefe", Sonsuza Tanıklık, çev.: Özkan Gözel ve Zeynep Direk, 186. 
ağaç, resimde renk, dilsel eserde sözler, müzik eserlerinde sesler. Eserin şeyliği ve eserin şeysel yönünden öte Heidegger'in vurgulamak istediği husus şeyliğin hep sanat eserinde açığa çıkması hususudur. Çünkü sanat eseri şeyselliğinin ötesinde ve üzerinde başka bir şey söyler (alegori) ve yapılmış bir şey olarak sanat eseri insanı başka olanla bir araya getirir (sembol). Dolayısıyla sanat eserinde bir şeyin kendisi veya biçimlenmiş malzeme değil, bizatihi o şeyin şeyliği açığa çıkar. Şeylerin şeyliği açığa çıktıkça buna şahit olan kimse kendisine gelebilecek ve kendisini bulabilecektir.

Sanat tarihseldir ve tarihsel olarak eserdeki hakikatin yaratıcı korunumudur. Sanat edebiyat olarak gerçekleşir. Bu ise hediye etme, kurma ve başlangıç anlaminda hediyedir. Sanat, oluşturucu olarak önemli oranda tarihseldir. Sanat, zamanın akışında diğerlerinin yanında mevcut olması ve tarihe değişen bir görünüm sunması yönleriyle, dışsal olarak da tarihseldir. Sanat, tarihi kurması anlamında da tarihtir. ${ }^{28}$

Gadamer, Heidegger' in bu tezini "orada oluşuyla bizim kendi varlığımıza tanıklık eden şiirsel söz" şeklinde geliştirirken insanın kendini dilde evinde hissetmesi, dille kurduğu aşinalık ve yakınlığa işaret eder. Kastettiği husus poetik sözün insana kendini evinde hissetme noktasında bir devamlılık sağlaması değildir. Çünkü poetik sözde sadece aşinalık değil, hala cevap aradığımız ucu açık sorularla karşılaşırız. Hep bir ölçüde tanıdık olmalarına karşın, bir eser içerisinde karşılaşıldığında, ölüm ve doğum, ıstırap ve suçluluk ya da bu gibi "sınır durumlar" tanımadığımız şeylikte görünür hale gelir. Bir ayna olarak şiirsel sözde ne dünyanın kendisi ne de dünyadaki şu ya da bu şey görülür. Orada görülen, kendimizi bir süreliğine evimizde hissetme (Einshausung) yakınlık veya aşinalığının kendisidir. Dolayısıyla poetik sözün gizemli ses ve anlam ilişkisinde bir tarihe tanıklık etmek, bir şeyin kendisinin değil de o şeyin şeyliğinin tarihte nasıl açığa çıktığı sadece geçmiş ve şimdiyle değil, aynı zamanda şimdi ve gelecekle bağlantılı olarak mümkündür, diğer deyişle edebi tanıklık "sözün "orada" olanı çağırıp onu hissedilebilir kadar yakınlığa getirmesidir." 29

Bu noktada Heidegger'in kendi sonluluğunun farkında olan ve bunu kararlı bir şekilde kabul eden Dasein'in tarihselliği kavramı ile tarihselci düşüncenin tarih-üstü, sonsuz ve her zaman var olan bir

28 Martin Heidegger, Sanat Eserinin Kökeni, çev.: Fatih Tepebaşıll, (Ankara: De Ki Yayınları, 2011), 73.

29 Gadamer, "On the Contribution of Poetry to the Search for Truth", 115. 
zihne sahip tarihçi (edebiyat tarihçisi) tasarımı arasında bir karşıtlık oluşur. 'Bir eser ancak dönemine bakılarak anlaşılabilir' denildiğinde sanki içinde yaşanılan dönemden çıkılıp, istenilen döneme geri dönülebilirmiş, sanki zamandan, tarihten bağımsızlık mümkünmüş gibidir. Buna karşılık Heidegger'de sanat eserinde açığa çıkan şeyin şeyliği, ona tanıklık etmiş kimseyi kendi zamanına ait k1larken kendi sonluluğunu da ona hatırlatır. Eğer tarih süregiden bir şeyse, tarihçi de ancak tarihin bir parçasıysa bu durumda tarihçi başka bir zamana nasıl yönelecek, ona nasıl ulaşabilecektir? Tarihçi içinde yaşadığı anı asla ve asla aşamaz. Her bir insan tarihi eserler gibi, tarihte yaşamış insanlar gibi kendi tarihinin bir parçasıdır. Tarihselci düşünceye sahip Dilthey "tarih bize aittir" derken Gadamer bunun tersine "biz tarihe aitiz" ${ }^{30}$ diyerek konuyu ontolojik bir düzleme taşır.

Böylece sanat eserleri araç özelliğini yitirmiş araçlar olarak ortaya çıktıklarında, diğer deyişle "bir başka şey için bir şey" olarak bir başka amaca hizmet etmeye direnç gösterdiklerinde tarih-üstü tasarıma sahip tarihselcinin edebi eserle kuracağı ilişki sorunlu hale gelmektedir. Dolayısıyla sanat eserini bir felakete veya köylünün ayakkabısına tanıklık eden bir "şey" olarak değil de felaketin veya köylü ayakkabısının hakiki özüne, şeyin şeyliğine tanıklık etme imkânı olduğu düşüncesi belirginleşir. O bu tanıklığa sadece Heidegger'in tabiriyle "kendi-içinde durma" (standing-in-itself) veya Gadamer' in tabiriyle "orada olma" olgusuyla izin verir. Sanat eseri şu hâlde tanık olunabilecek bir dünya açar. Tanıklık gündelik olağanlığın ötesinde bir duruma tanıklık etmekse bu ancak sanat eserinin evsizliğinde imkân kazanır. Böylece "hiç kimse bir dünya açan sanat eserinde sadece daha önce bilinmeyen bir şeyin tecrübe edilmesi için verilen anlamlı bir şey değil, aynı zamanda sanat eserinin kendisiyle birlikte açığa çıkan yeni bir şey olduğu gerçeğini göz ardı edemez." 31

\section{Sonuç}

Sonuç olarak edebi eser tarihselci yaklaşımda tinin şeyleşmesi, diğer deyişle zaten var olan bir şeyin kopyalanması şeklinde geçmişe tanıklık ettiği düşünülen bir vesika olarak ele alındığında ortada bir

\footnotetext{
30 Hans-Georg Gadamer, Hakikat ve Yöntem, çev.: Hüsamettin Arslan ve İsmail Yavuzcan, (İstanbul: Paradigma Yayıncilık, 2009), c. II, 20.

31 Hans-Georg Gadamer, "The Truth of the Work of Art", Heidegger's Way, trans.: John W. Stanley, (Albany, State University of New York Press, 1994), 105.
} 
edebi eser kalmayacağından edebi eserin tanıklığı ifadesi anlamsızlaşır. İçinde bir tarihin ortaya çıktığı sanat eserinde yapısalcılığın salt dilsel forma veya göstergeye tanıklık etmesi de mümkün değildir. Okurun öznelliği ise edebi eserin diğer söylem biçimlerinden farkına bir biçimde riayet etse de tanıklığa tanık olan öteki okurları büyük ölçüde dışladığında bu kez de tanıklığı imkânsız hale getirmektedir. Bunların ötesinde edebiyat belgeleştirilemezlik ve kendiiçinde-durma vasfıyla şeyin şeyliğini açığa vurarak ürettiği özgün ve yeni tarihe, tarihi-aşarak tanıklık etmeyi sürdürebilmektedir.

\section{Kaynakça}

Adorno, Theodor. "Kültür Eleştirisi ve Toplum”, Edebiyat Yazıları. Çev. Sabir Yücesoy ve Orhan Koçak, İstanbul: Metis Yayınları, 2008, 159179.

Arendt, Hannah. Kötülü̈̆̈̈̈n Stradanlı̆̆ı: Adolf Eichmann Kudüs'te. Çev. Özge Çelik, İstanbul: Metis Yayınları, 2012.

Berlin, Isaiah. Romantikliğin Kökleri. haz.: Henry Hardy, Çev. Mete Tunçay, İstanbul: Yapı Kredi Yayınları, 2004.

Derrida, Jacques. "Poetics and Politics of Witnessing", Sovereignties in Question: The Poetics of Paul Celan. Ed. Thomas Dutoit and Outi Pasanen, New York: Fordham University Press, 2005, 65-96.

Derrida, Jacques. Edebiyat Edimleri. Çev. Mukadder Erkan ve Ali Utku, İstanbul: Otonom Yayıncilik, 2009.

Dilthey, Wilhelm. Hermeneutik ve Tinbilimleri. Çev. Doğan Özlem, İstanbul: Paradigma Yayınları, 1999.

Erkol, Çimen Günay. “Taş Üstüne Taş Koymak: 12 Mart Romanlarında Görgü Tanığı Belleğinin Yazınsallaştırılması", Nasıl Hatırlıyoruz? Türkiye'de Bellek Çalışmaları. İstanbul: Türkiye İş Bankası Yayınları, 2011, 41-63.

Gadamer, Hans-Georg. "Aesthetics and Hermeneutics”, Philosophical Hermeneutics. trans. and ed.: David E. Linge, Berkeley, Los Angeles, London: University of California Press, 2008, 95-104.

Gadamer, Hans-Georg. "On the Contribution of Poetry to the Search for Truth", The Relevance of the Beautiful and Other Essays. ed.: Robert Bernasconi, trans.: Nicholas Walker, Cambridge: Cambridge University Press, 1986, 105-115.

Gadamer, Hans-Georg. "The Truth of the Work of Art", Heidegger's Way. trans.: John W. Stanley, Albany, State University of New York Press, 1994, 95-109.

Gadamer, Hans-Georg. Hakikat ve Yöntem. c. II. Çev. Hüsamettin Arslan ve İsmail Yavuzcan, İstanbul: Paradigma Yayıncılık, 2009. 
Tarihselciliğgin ve Formalizmin Ötesinde Edebiyatın Tanıklığı

Gündoğdu, Atiye Gülfer. “Okurla Dil Arasındaki Şüphe ve Güven İlişkisinin Edebi Metnin Anlamına Etkisi", Dinbilimleri Akademik Araştırma Dergisi. 17/2, 2017, 93-110.

Hesiodos, Theogonia - İşler ve Günler. Çev. Azra Erhat ve Sabahattin Eyüboğlu, Ankara: Türk Tarih Kurumu Basımevi, 1977.

https://www.etymonline.com/word/martyr\#etymonline_v_9661, Erişim Tarihi: 23.10.2019.

Jakobson, Roman. "Linguistics and Poetics", Language in Literature. ed.: Krystyna Pomorska and Stephen Rudy, Cambridge MA: Harvard University Press, 1987, 62-94.

Jauss, Hans Robert. "Bilimsel Bir Yazın Tarihinin Çağırışı”, Çev. Tevfik Turan, Bağlam Dergisi. İstanbul: 1980, 2, 89-122.

Levinas, Emmanuel. "Etik ve Sonsuz", Sonsuza Tanıklk. haz.: Zeynep Direk ve Erdem Gökyaran, Çev. Özkan Gözel, İstanbul: Metis Yayınları, 2003, 295-344.

Levinas, Emmanuel. “Tanrı ve Felsefe”, Sonsuza Tanıklık. haz.: Zeynep Direk ve Erdem Gökyaran, Çev. Özkan Gözel ve Zeynep Direk, İstanbul: Metis Yayınları, 2003, 163-190.

Martin Heidegger, Sanat Eserinin Kökeni. Çev. Fatih Tepebaşılı, Ankara: De Ki Yayınları, 2011.

Ricoeur, Paul. Eleştiri ve İnanç: F. Azouvi ve M. De Launay ile Söyleşi, Çev.: Mehmet Rifat, İstanbul: Yapı Kredi Yayınları, 2010.

Ricoeur, Paul. Hafıza, Tarih, Unutuş. Çev. M. Emin Özcan, İstanbul: Metis Yayınları, 2012.

Ricoeur, Paul. Zaman ve Anlatı: İki-Tarih ve Anlatı. Çev. Mehmet Rifat, İstanbul: Yapı Kredi Yayınları, 2009.

Sasu, Laura. "Witness Literature-A Conceptual Framework", Bulletin of the Transilvania University of Braşov. Series IV: Philology \& Cultural Studies, Vol. 6, no: 2, 7-12.

Tatar, Burhanettin. "Tarihsel Hadis Bilincinin Rehabilitasyonu", Ondokuz Mayıs Üniversitesi İlahiyat Fakültesi Dergisi. 2001, sayı: 12-13, 583-593.

Wellek, Rene. “Edebiyat Nazariyesi, Tenkidi ve Tarihi”, Ondokuz Mayıs Üniversitesi Eğitim Fakültesi Dergisi, Çev. Sıddık Yüksel, Samsun, 1992, 2/1, 316-331.

Wiesel, Elie. "The Holocaust as a Literary Inspiration", Dimensions of the Holocaust. ed.: Elliot Leifkovitz, Evanston, Illinois: Northwestern University Press, 1977. 